\section{Commentary: Overpromised, understudied: The slippery slope of pediatric cardiac device development}

\author{
Charles D. Fraser, Jr, MD
}

A legendary scientist in the Department of Engineering at the University of Texas-Austin was renowned for the tough admonition, his "researcher's creed," that he gave students proposing research in his laboratory: "Believe nothing, doubt everything, demand proof." These cynical yet prophetic words should be applicable to much of what we do in pediatric cardiac surgery, and particularly the choices we make in placing new devices in children.

During the course of my career as a pediatric cardiac surgeon, I have relearned this bitter lesson too many times: if something sounds too good to be true, it probably is. There are many examples of this reality. We thought the DeBakey Child ventricular assist device (VAD) was going to revolutionize durable mechanical circulatory support in children. We were wrong. ${ }^{1,2} \mathrm{We}$ believed that the Contegra bovine jugular valved conduit would offer a lower long-term risk profile in terms of durability and freedom from infection. It does not. ${ }^{3} \mathrm{We}$ were confident that the risk profile of the Berlin Heart pediatric VAD was adequately established. It had not been. ${ }^{4}$ We are not alone in these experiences. The Sorin tissue valve did not perform well in children and had to be recalled with a warning to patients/families. ${ }^{5}$ The Shelhigh valved conduit performance and integrity in both the right and left ventricular outflow tract positions were unacceptable. ${ }^{6}$ In this issue of the Journal, we learn more about the performance of small intestinal submucosa patches and valve constructs, and the information is disappointing.

\footnotetext{
From the University of Texas Dell Medical School, Dell Children's Medical Center, Austin, Tex.

Disclosures: Author has nothing to disclose with regard to commercial support.

Received for publication Oct 28, 2019; revisions received Oct 28, 2019; accepted for publication Oct 28, 2019; available ahead of print Nov 20, 2019.

Address for reprints: Charles D. Fraser, Jr, MD, Texas Center for Pediatric and Congenital Heart Disease, Dell Children's Medical Center, 4900 Mueller Blvd, Suite 3S.003, Austin, TX 78723 (E-mail: Charles.fraser@ austin.utexas.edu). J Thorac Cardiovasc Surg 2020;160:e221-2 $0022-5223 / \$ 36.00$

Copyright (c) 2019 by The American Association for Thoracic Surgery https://doi.org/10.1016/j.jtcvs.2019.10.171
}

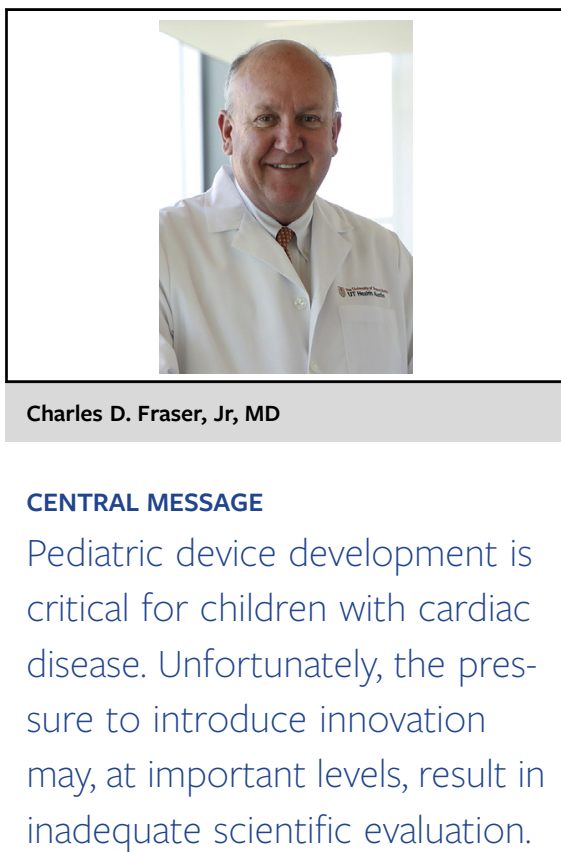

Why does this keep happening? Why do we jump on the "bandwagon" of new devices and materials for use in complex cardiac conditions in children? Most importantly and appropriately, we all sincerely want better options for our patients who have bad problems-a durable VAD with a low-risk profile, a better valved conduit, patch material that promotes native tissue ingrowth. We know that in pediatric cardiac surgery, developing innovative devices may be much more difficult when compared with our counterparts in adult cardiac surgery-start-up capital is scarce, the regulatory pathways onerous, grant funding opportunities limited and challenging, and the potential market small-the proverbial "Valley of Death" for new devices. And... of course, we have the realities of somatic growth and differences of biology in childhood to contend with in our research efforts. So, when something comes along that looks good, we are hopeful. We are early adopters. Sometimes it works out, sometimes not.

It is undeniable that devices and materials that we use in pediatric cardiac surgery are not always adequately tested before being used in patients. For a given situation or clinical need, this may or may not be justifiable. Unfortunately, there is also another element that remains, at minimum, controversial; at worst, unethical. As the authors of the current paper allude to in their discussion section, there is the ongoing reality of conflict of interest 
in research that is performed in device development. ${ }^{7}$ Is acknowledging equity ownership in the "small print" of a scientific article sufficient to eliminate reasonable concerns about data integrity and interpretation? Or should we demand that investigators who are involved in the critical analytic steps that lead to human device implantation be completely distanced from any real or perceived financial conflict of interest? Tough questions when one considers the desperate need for solutions, the paucity of options in critical settings, and limited resource opportunities. Unfortunately, it can be a slippery slope. The pressures to get devices into patients are real and compelling. When it comes to scientific evaluation of new technology for children, however, it may be best to "believe nothing, doubt everything, and demand proof."

\section{References}

1. Morales DLS, DiBardino DJ, Fraser CD Jr. The DeBakey VAD child: first implantable ventricular assist device for children in the United States. Pediatr Cardiol Today. 2004;2:1-5.

2. Fraser CD Jr, Carberry KE, Owens WR, Arrington KA, Morales DL, Heinle JS, et al. Preliminary experience with the Micromed DeBakey Pediatric Ventricular Assist Device. Semin Thorac Cardiovasc Surg Pediatr Card Surg Annu. 2006;109-14.

3. Beckerman Z, De Leon L, Zea-Vera R, Mery C, Fraser CD Jr. High incidence of late infective endocarditis in bovine jugular vein valved conduits. J Thorac Cardiovasc Surg. 2018;156:728-34.

4. Fraser CD Jr, Jaquiss RDB, Rosenthal DN, Humpl T, Canter CE, Blackstone EH, et al. Prospective trial of a pediatric ventricular assist device. N Engl J Med. 2012; 367:532-41.

5. Saleeb SF, Newburger JW, Geva T, Baird CW, Gauvreau K, Padera RF, et al. Accelerated degeneration of a bovine pericardial bioprosthetic aortic valve in children and young adults. Circulation. 2014;130:51-60.

6. Pearl JM, Cooper DS, Bove KE, Manning PB. Early failure of the Shelhigh pulmonary valve conduit in infants. Ann Thorac Surg. 2002;74:542-9.

7. van Rijswijk JW, et al. Failure of decellularized porcine small intestinal submucosa as a heart valved conduit. J Thorac Cardiovasc Surg. 2020;160:e201-15.
See Article page e201.

\section{Commentary: "CorMatrix: If it is too good to be true, ..."}

\section{Francesco Formica, MD, ${ }^{\mathrm{a}}$ and Tain-Yen Hsia, $\mathrm{MD}^{\mathrm{b}}$}

The search for a perfect substitution material in reconstructive cardiovascular surgery continues. Ideally, such material will possess these properties: freedom from calcification, traction, and retraction; fully biocompatibility; resistant to infections, inflammation, and fibrosis; easy to handle; and promotes tissue remodeling and regeneration while allowing for growth. Numerous substitute materials, either biological and synthetic, have been applied in cardiac valve repair, ventricle walls, and great vessels reconstruction. Although we have extensive experience with autologous pericardium, xenopericardium, homograft, polyethylene (Dacron) and polytetrafluoroethylene (Gore-Tex) materials, none proved to be completely satisfactory. Biological

From the a Cardiac Surgery Unit, San Gerardo Hospital, Department of Medicine and Surgery, University of Milano-Bicocca, Monza, Italy; and ${ }^{\mathrm{b}}$ Pediatric Cardiac Surgery, Yale New Haven Children's Hospital, New Haven, Conn.

Disclosures: Authors have nothing to disclose with regard to commercial support.

Received for publication Nov 9, 2019; accepted for publication Nov 12, 2019; available ahead of print Nov 29, 2019.

Address for reprints: Francesco Formica, MD, Clinica Cardiochirurgica Ospedale San Gerardo, ASST Monza Via G.B. Pergolesi 33, 20052, Monza (MB), Italy (E-mail: francesco_formica@fastwebnet.it).

J Thorac Cardiovasc Surg 2020;160:e222-3

0022-5223/\$36.00

Copyright (c) 2019 by The American Association for Thoracic Surgery

https://doi.org/10.1016/j.jtcvs.2019.11.043
Check for updates

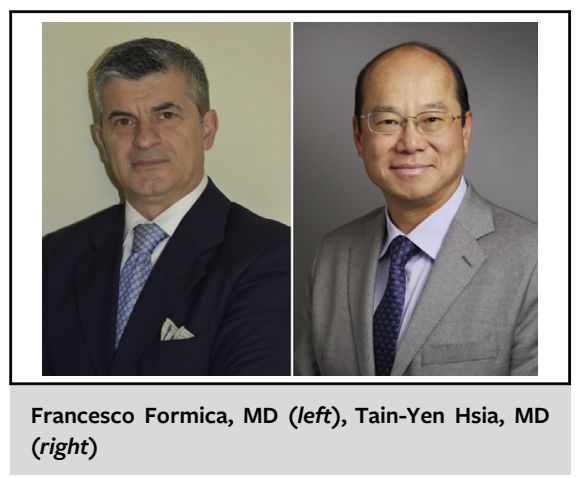

CENTRAL MESSAGE

In animal studies, pulmonary

valve conduit made with CorMa-

trix showed a high incidence of

early valve failure and infection, with corresponding histologic

features of inflammation and

poor remodeling.

material will inevitably degenerate and calcify, and there is no growth potential in any of the synthetic options.

Since its introduction more than 20 years ago, decellularized porcine small intestinal submucosa (CorMatrix Cardiovascular, Inc, Roswell, Ga), has been tested in a variety of reconstructive cardiovascular operations. Its 